\title{
PHÂN TÍCH CÁC YẾU TỐ ẢNH HƯởNG ĐẾN TÌNH TRẠNG NGHÈO ĐÓI TẠI TỈNH TRÀ VINH
}

\author{
HUỲNH QUANG LINH \\ Trường Đại họ Trà Vinh; \\ huynhquanglinh@tvu.edu.vn
}

\begin{abstract}
Tóm tắt. Công trình nghiên cứu này tập trung kiểm chứng những yếu tố ảnh hưởng đến khả năng rơi vào diện nghèo đói của các hộ gia đình tại tỉnh Trà Vinh. Một mô hình nghiên cứu với 11 biến độc lập và một biến phụ thuộc đã được thiết lập. Nghiên cứu đã tiến hành một cuộc khảo sát với sự tham gia của 228 hộ gia đình ở 57 xã nghèo của tỉnh Trà Vinh. Dữ liệu sau khi thu thập được phân tích bằng thủ tục hồi quy nhị phân Binary Logistic. Kết quả từ phân tích chứng minh rằng, chỉ có 7 biến trong 11 biến độc lập là có ảnh hưởng thống kê đến khả năng rơi vào diện nghèo đói của các hộ gia đình ở tỉnh Trà Vinh với mức ý nghĩa từ $1 \%$ đến $10 \%$. Kết quả từ công trình nghiên cứu này kỳ vọng sẽ hữu ích cho lãnh đạo tỉnh Trà Vinh trong công cuộc xóa đói giảm nghèo cho cư dân địa phương.
\end{abstract}

Từ khóa. Nghèo đói; Hộ nghèo; Giảm nghèo

\section{ANALYSIS OF FACTORS AFFECTING POVERTY IN TRAVINH PROVINCE}

\begin{abstract}
This research seeks to investigate the factors affecting the probability that households in Tra Vinh province fall in poverty. The research model with 11 independent variables and a dependent variable was developed. A survey was conducted with 228 households in the 57 poor communes of Tra Vinh province. The collected data was analyzied with the Binary Logistic Regression procedure. The findings offer evidence that only 7 variables of the 11 independent ones statistically affect the probability of falling in poverty by households in Tra Vinh province at the significance levels of from $1 \%$ to $10 \%$. The results from this research are helpful to the leaders of Tra Vinh province in eradicating hunger and alleviating poverty for local people.
\end{abstract}

Keywords. Poverty; Poor household; Poverty reduction

\section{GIỚI THIỆU}

Nghèo đói là vấn đề mang tính toàn cầu. Ngày nay, đói nghèo đang trở thành một vấn đề cấp bách của nhiều quốc gia trên thế giới, đặc biệt là ở các nước đang phát triển, trong đó có Việt Nam. Ở Việt Nam, công tác xóa đói giảm nghèo là mục tiêu xuyên suốt trong quá trình phát triển kinh tế, xã hội của đất nước. Nó là yếu tố cơ bản để đảm bảo dân giàu, nước mạnh, xã hội công bằng và tăng trưởng kinh tế bền vững, đáp ứng mục tiêu do Đảng ta đề ra (Nguyễn Thị Ánh và Nguyễn Thị Nghĩa 2014). Các tác giả này cũng cho rằng, mặc dù tỷ lệ nghèo ở Việt Nam những năm gần đây đã giảm đáng kể, song nhìn chung nghèo vẫn còn tập trung phần lớn ở khu vực nông thôn, vùng sâu vùng xa. Thêm vào đó, Hoàng Triều Hoa (2014) khẳng định, tập trung triển khai các chương trình xóa đói giảm nghèo ở vùng sâu, vùng xa, vùng đặc biệt khó khăn là mục tiêu xóa đói giảm nghèo bền vững của Đảng và Chính phủ ta. Trà Vinh được chia làm 7 huyện, 1 thị xã và 1 thành phố, trong đó, có đến $83 \%$ dân số sống ở vùng nông thôn. Điều này cho thấy nền kinh tế của Trà Vinh vẫn còn dựa vào nông nghiệp là chủ yếu. Trong những năm qua, lãnh đạo tỉnh Trà Vinh đã đầu tư không ít công sức vào việc tìm kiếm những nguồn hỗ trợ từ các tổ chức trong và ngoài nước, nhằm tăng cường nguồn lực cho việc thúc đẩy phát triển kinh tế- xã hội của tỉnh nhà; từ đó sẽ thúc đẩy giảm nghèo và nâng cao đời sống và thu nhập cho người dân ở vùng nông thôn. Những cố gắng của lãnh đạo tỉnh Trà Vinh trong thời gian qua đã mang lại hiệu quả to lớn cho công cuộc xóa đói giảm nghèo của địa phương. Cụ thể tỷ lệ hộ nghèo giảm đáng kể, từ gần $24 \%$ vào năm 2010 , xuống còn nhỏ hơn $11 \%$ vào năm 2014 (Cục Thống kê tỉnh Trà Vinh 2015). Tuy nhiên, tỷ lệ hộ nghèo ở tỉnh nhà vẫn còn khá cao. Năm 2014, tỷ lệ hộ nghèo của tỉnh Trà Vinh là khoảng $11 \%$; trong khi đó, tỷ lệ 
hộ nghèo của tỉnh Long An là khoảng $3 \%$, của tỉnh Vĩnh Long là 3,5\%. Con số này cho thấy rằng, Trà Vinh là một trong những tỉnh nghèo nhất ở Đồng Bằng Sông Cửu Long, cũng như cả nước; điều này có thể là do điều kiện phát triển kinh tế của tỉnh còn khó khăn, trình độ dân trí thấp, giao thông còn trở ngại (Cục Thống kê tỉnh Trà Vinh 2015). Do đó, ban lãnh đạo tỉnh Trà Vinh cần phải cố gắng hơn nữa để giảm tỷ lệ hộ nghèo ở tỉnh nhà xuống mặt bằng chung của các tỉnh Đồng Bằng Sông Cửu Long cũng như của cả nước. Để thực hiện được mục tiêu này, cần có những nghiên cứu liên quan đến tình trạng nghèo đói của cư dân tỉnh Trà Vinh. Vì vậy, công trình nghiên cứu đánh giá khả năng nghèo đói của cư dân tỉnh Trà Vinh có ý nghĩa lớn cho công cuộc xóa đói giảm nghèo của đất nước, của đồng bằng sông Cửu Long nói chung, và của tỉnh Trà Vinh nói riêng.

\section{CƠ SỞ LÝ THUYẾT}

Theo quan điểm của Ngân hàng Thế giới- World Bank (2000); nghèo đói là tình trạng một bộ phận dân cư không được hưởng và thoả mãn những nhu cầu cơ bản của con người đã được xã hội thừa nhận tuỳ theo trình độ phát triển kinh tế xã hội và phong tục tập quán của các địa phương; do vậy mức độ nghèo đói ở các nước khác nhau là khác nhau. Giới hạn nghèo đói của các quốc gia được xác định bằng mức thu nhập tối thiểu để người dân có thể tồn tại được, đó là mức thu nhập mà một hộ gia đình có thể mua sắm được những vật dụng cơ bản phục vụ cho việc ăn, mặc, ở và các nhu cầu thiết yếu khác theo mức giá hiện hành. Ở Việt Nam, căn cứ vào tình hình kinh tế xã hội và mức thu nhập của nhân dân trong những năm qua thì khái niệm nghèo đói được xác định là tình trạng một bộ phận dân cư chỉ có những điều kiện thoả mãn những nhu cầu tối thiểu và cơ bản nhất trong cuộc sống và có mức sống thấp hơn mức sống của cộng đồng xét trên mọi phương diện. Một cách hiểu khác, nghèo đói là một bộ phận dân cư có mức sống dưới ngưỡng quy định của sự nghèo. Nhưng ngưỡng nghèo còn phụ thuộc vào đặc điểm cụ thể của từng địa phương, từng thời kỳ cụ thể hay từng giai đoạn phát triển kinh tế xã hội cụ thể của từng địa phương hay từng quốc gia (Ngân hàng Thế giới- World Bank 2012). Việt Nam ngày càng phát triển nhưng vẫn còn bị xếp vào nhóm các nước nghèo của thế giới với tỷ lệ hộ đói nghèo còn khá cao.

Theo Nguyễn Minh Hà và cộng sự (2013), xóa đói giảm nghèo tại các địa phương là chủ trương của Đảng và Nhà nước ta. Mỗi năm Nhà nước luôn dành một khoảng để chăm lo đời sống cho người nghèo và tìm nhiều phương cách giúp họ thoát nghèo. Giải quyết vấn đề nghèo là một trong những vai trò điều tiết nền kinh tế của Nhà nước, thể hiện qua việc xây dựng một hệ thống các chính sách nhằm hỗ trợ cho người nghèo. Quan niệm về nghèo đang ngày một thay đổi và ngày càng phản ánh rõ bản chất của nghèo; chính vì vậy, hệ thống các giải pháp chính sách nhằm giảm nghèo của chính phủ cũng luôn phải thay đổi cho phù hợp. Để có những đề xuất hữu ích trong công tác xóa đói giảm nghèo, cần phải có những nghiên cứu đánh giá các nhân tố tác động đến khả năng rơi vào diện nghèo đói của cư dân địa phương. Trước hết cần xác định được chuẩn nghèo, tức là phải biết mức thu nhập bao nhiêu là nghèo, bao nhiêu là cận nghèo, và bao nhiêu là thoát nghèo. Chuẩn nghèo là tiêu chí nhằm xác định ai là người nghèo để thực hiện các chính sách hỗ trợ giảm nghèo của Nhà nước, nhằm bảo đảm công bằng trong thực hiện các chính sách giảm nghèo. Căn cứ vào mức sống thực tế các địa phương, trình độ phát triển kinh tế xã hội, từ năm 1993 đến năm 2015, Bộ Lao động. Thương binh và Xã hội đã 6 lần công bố tiêu chuẩn cụ thể cho hộ nghèo. Các tiêu chí này thay đổi theo thời gian cùng với sự thay đổi mặt bằng thu nhập quốc gia. Quyết định số 09/QĐ-TTg ngày 30/01/2011 của Thủ tướng Chính phủ quy định chuẩn nghèo cho các hộ dân cư tại các địa phương như sau đây. Hộ nghèo là hộ có mức thu nhập từ 400.000 đồng/người/tháng trở xuống ở vùng nông thôn, có mức thu nhập từ 500.000 đồng/người/tháng trở xuống ở vùng thành thị. Hộ cận nghèo là hộ có mức thu nhập từ 401.000- 520.000 đồng/người/tháng trở xuống ở vùng nông thôn, có mức thu nhập từ 501.000- 650.000 đồng/người/tháng trở xuống ở vùng thành thị. Ngoài các mức trên là hộ thoát nghèo hoặc không nghèo.

Các nghiên cứu trước đây nhận định khác nhau về các yếu tố ảnh hưởng đến xác suất nghèo đói của người dân. Phạm Anh Tuấn và cộng sự (2003) đề nghị các yếu tố sau đây có ảnh hưởng đến nghèo đói: thiếu vốn sản xuất, gia đình đông nhân khẩu, thiếu công ăn việc làm, thiếu đất sản xuất, thiếu kinh nghiệm. Tương tự, Lê Đại Trí và cộng sự (2003) và Phạm Văn Ngọc và cộng sự (2003) cũng xác nhận rằng xác suất nghèo đói là do các nhân tố sau đây gây nên: thiếu kinh nghiệm, có ít đất sản xuất, có ít lao 
động, rủi ro, thiếu vốn sản xuất, điều kiện tự nhiên khắc nghiệt, cơ sở hạ tầng kém, thị trường kém phát triển, các chương trình, chính sách của Nhà nước kém hiệu quả; trong khi, Ngô Thị Lệ Thủy (2006) cho thấy các yếu tố ảnh hưởng đến nghèo đói là do: thiếu vốn sản xuất, không có kinh nghiệm, thiếu công ăn việc làm, đất canh tác ít, trình độ văn hóa thấp, gia đình đông nhân khẩu, lười biếng, nghiện hút, rủi ro. Thêm vào đó, theo Võ Ngọc Ánh (2008), có nhiều yếu tố ảnh hưởng đến nghèo đói; bao gồm: có ít đất canh tác, thiếu vốn sản xuất, trình độ học vấn thấp, nghề nghiệp bấp bênh và khả năng áp dụng khoa học kỹ thuật còn thấp. Trong khi đó, Nguyễn Thị Hoàng Phượng (2009) xác nhận các yếu tố dẫn đến nghèo bao gồm: trình độ văn hóa thấp, không có nghề nghiệp ổn định, thiếu vốn sản xuất, tuổi tác, giới tính, dân tộc. Các nghiên cứu trên cho thấy rằng, các yếu tố ảnh hưởng đến nghèo đói ở từng khu vực là khác nhau. Nhìn chung, sự nghèo đói thường do các yếu tố sau tác động: thiếu vốn sản xuất, đất canh tác ít, trình độ văn hóa thấp, hộ đông nhân khẩu, số hoạt động tạo thu nhập, tuổi tác, nghề nghiệp chính của hộ gia đình, thiếu công ăn việc làm, thiếu sự hỗ trợ của chính quyền địa phương, giới tính, dân tộc. Lập luận của các nghiên cứu được đề cập ở trên có thể giúp đi đến đề xuất các giả thuyết nghiên cứu sau đây cho công trình nghiên cứu này.

Giả thuyết GT1: Vốn sản xuất của hộ có ảnh hưởng đến xác suất nghèo đói của hộ gia đình

Giả thuyết GT2: Diện tích đất canh tác của hộ có ảnh hưởng đến xác suất nghèo đói của hộ gia đình Giả thuyết GT3: Trình độ học vấn của chủ hộ có ảnh huởng đến xác suất nghèo đói của hộ gia đình Giả thuyết GT4: Số nhân khẩu trong hộ có ảnh huởng đến xác suất nghèo đói của hộ gia đình Giả thuyết GT5: Số hoạt động tạo thu nhập của hộ có ảnh huơong đến xác suất nghèo đói của hộ gia dinh

Giả thuyết GT6: Độ tuổi trung bình của hộ có ảnh huởng đến xác suất nghèo đói của hộ gia đình Giả thuyết GT7: Nghề nghiẹp chính của hộ có ảnh huởng đến xác suất nghèo đói của hộ gia đình Giả thuyết GT8: Tính ổn định về công ăn việc làm của chủ hộ có ảnh hưởng đến xác suất nghèo đói của hộ gia đình

Giả thuyết GT9: Sư hỗ trợ của Nhà nước/ Chính quyền địa phương có ảnh huởng đến xác suất nghèo đói của hộ gia đình

Giả thuyết GT10: Giới tính của chủ hộ có ảnh huơong đến xác suất nghèo đói của hộ gia đình

Giả thuyết GT11: Loại dân tộc của hộ có ảnh hưởng đến xác suất nghèo đói của hộ gia đình

\section{THIẾT KẾ NGHIÊN CÚU}

\subsection{Mô hình nghiên cứu}

Dựa vào các giả thuyết nghiên cứu trên đây về các yếu tố ảnh hưởng đến xác suất nghèo đói của hộ gia đình dân cư, chúng ta có thể xây dựng một mô hình nghiên cứu cho công trình nghiên cứu này. Mô hình nghiên cứu về mức độ nghèo đói được mô tả như phương trình (1). Sau khi xây dựng được mô hình nghiên cứu, nghiên cứu này tiếp tục với phần thiết kế nghiên cứu, mà nó trình bày cách đo lường các biến nghiên cứu, phương pháp thu thập và xử lý dữ liệu.

$\mathrm{Y}=\mathrm{f}(\mathrm{X} 1, \mathrm{X} 2, \mathrm{X} 3, \mathrm{X} 4, \mathrm{X} 5, \mathrm{X} 6, \mathrm{D} 1, \mathrm{D} 2, \mathrm{D} 3, \mathrm{D} 4, \mathrm{D} 5)$

Trong đó:

Y: Xác suất nghèo đói của hộ gia đình- Nhận giá trị 1 nếu hộ có mức thu nhập từ 520.000 đồng/người/tháng trở xuống ở vùng nông thôn, có mức thu nhập từ 650.000 đồng/người/tháng trở xuống ở vùng thành thị (hộ nghèo); ngược lại thì nhận giá trị 0 (hộ thoát nghèo hoặc không nghèo).

$\mathrm{X} 1$ : Vốn sản xuất- Là tổng số tiền vốn sử dụng của hộ gia đình cho sản xuất/năm (trđ/n)

X2: Diện tích đất canh tác- Là diện tích đất bình quân trên đầu người của hộ tính theo $\mathrm{m} 2$

X3: Trình độ học vấn- Là khoảng thời gian đi học của chủ hộ tính theo năm

X4: Số nhân khẩu- Số nhân khẩu trong hộ, nhận giá trị tương ứng với số người trong hộ

X5: Số hoạt động tạo thu nhập- Số hoạt động tạo thu nhập nhận giá trị tương ứng với số hoạt động tạo ra thu nhập của hộ

X6: Độ tuổi- Độ tuổi của lao động, nhận giá trị trung bình tròn số theo tuổi của các nhân khẩu trong tuổi lao động của hộ 
D1: Nghề nghiệp- Nếu nghề nghiệp chính của hộ là nông nghiệp nhận giá trị 1, ngược lại nhận giá trị 0

D2: Tình trạng việc làm- Nhận giá trị 1 nếu chủ hộ đang có việc làm ổn định, ngược lại nhận giá trị 0 (người có việc làm ổn định là người có tổng thời gian làm việc tạo ra thu nhập bình quân từ 20 ngày/tháng/năm trở lên, được quy định bởi Cục Thống kê Phú Thọ (2014))

D3: Sự hỗ trợ của Nhà nước/ Chính quyền địa phương cho hộ gia đình- Nhận giá trị 1 nếu được sự hỗ trợ của Nhà nước hay Chính quyền địa phương, giá trị 0 nếu không được hỗ trợ

D4: Giới tính- Biến này nhận giá trị 1 nếu chủ hộ là nam, nhận giá trị 0 nếu chủ hộ là nữ

D5: Dân tộc- Biến này nhận giá trị 1 nếu hộ gia đình là dân tộc Kinh, nhận giá trị 0 nếu hộ gia đình là dân tộc khác

\subsection{Phương pháp thu thập và xử lý dữ liệu}

Công trình nghiên cứu này sử dụng tổng cộng 12 biến nghiên cứu để phân tích. Theo đề nghị của Hair và cộng sự (2010), cỡ mẫu $\mathrm{n}=80+5^{*}$ số biến $=140$ quan sát. Để đảm bảo độ tin cậy thống kê, nghiên cứu này tiến hành điều tra khoảng 210 hộ gia đình tại tỉnh Trà Vinh (nhiều hơn khoảng $50 \%$ so với yêu cầu). Phương pháp chọn mẫu cho nghiên cứu này là phương pháp chọn mẫu phi ngẫu nhiên hạn ngạch. Theo Quyết định số 1049/QĐ-TTg của Thủ tướng Chính phủ phê duyệt danh sách các xã đặc biệt khó khăn, ngày 26 tháng 4 năm 2014, Trà Vinh có 57 xã thuộc 7 huyện thuộc loại xã khó khăn nghèo đói. Trong đó, huyện Châu Thành có 11 xã; huyện Cầu Kè có 6 xã; huyện Càng Long có 4 xã; huyện Trà Cú có 17 xã, huyện Tiểu Cần có 9 xã; huyện Cầu Ngang có 6 xã, và huyện Duyên Hải có 4 xã. Số đối tượng khảo sát trên mỗi xã khó khăn nghèo đói trên đây bình quân là 210/57=3,7 làm tròn thành 4 hộ, vì vậy tổng cộng số đối tượng điều tra là 228 hộ; để chọn 4 hộ khảo sát tại mỗi xã, phương pháp chọn mẫu thuận tiện được áp dụng (xem Bảng 1).

Dữ liệu thu thập được làm sạch và đưa vào phân tích. Tập dữ liệu thu thập có biến phụ thuộc là nhị phân, vì vậy phương pháp bình phương nhỏ nhất không còn là một ước lượng không chệch tốt nhất nữa. Mô hình phù hợp cho trường hợp này là mô hình probit hoặc mô hình logit; tuy nhiên tác động biên của mô hình probit là $\Phi(\beta X) \beta$ khó tính toán và giải thích hơn tác động biên của mô hình logit là $\beta \mathrm{P}(1-\mathrm{P})$. Do đó, phương pháp phân tích hồi quy nhị phân Binary Logistic (logit) được chọn để kiểm định sự phù hợp của mô hình nghiên cứu đề xuất và kiểm định các giả thuyết GT1, GT2, GT3, GT4, GT5, GT6, GT7, GT8, GT9, GT10 và GT11. Chọn xác suất ban đầu của khả năng hộ nghèo là 0,5 , thì tác động biên bằng $\beta$.

Bảng 1: Phân bổ mẫu khảo sát

\begin{tabular}{|c|c|c|c|}
\hline TT & Đơn vị hành chánh & Số lượng xã nghèo & Sống lượng hộ khảo sát \\
\hline 01 & Huyện Châu Thành & 11 & 44 \\
\hline 02 & Huyện Cầu Kè & 6 & 24 \\
\hline 03 & Huyện Càng Long & 4 & 16 \\
\hline 04 & Huyện Trà Cú & 17 & 68 \\
\hline 05 & Huyện Tiểu Cần & 9 & 36 \\
\hline 06 & Huyện Cầu Ngang & 6 & 24 \\
\hline 07 & Huyện Duyên Hải & 4 & 16 \\
\hline & Tổng cộng & $\mathbf{5 7}$ & $\mathbf{2 2 8}$ \\
\hline
\end{tabular}

\section{KẾT QUẢ NGHIÊN CÚU}

Trước khi phương pháp phân tích hồi quy nhị phân Binary Logistic được sử dụng để kiểm định sự phù hợp của mô hình nghiên cứu đề xuất và kiểm định các giả thuyết GT1, GT2, GT3, GT4, GT5, GT6, GT7, GT8, GT9, GT10 và GT11, dữ liệu thô được làm sạch. Làm sạch dữ liệu là bước rà soát lại dữ liệu, 
là quy trình nhằm đảm bảo rằng các dữ liệu đều đúng và chính xác.

Kết quả từ Bảng 2 cho biết rằng, hệ số tương quan Cox \& Snell-R2 đạt 0,354 ; con số này hàm ý rằng, 35,4\% sự thay đổi của tình trạng nghèo đói của hộ gia đình tại tỉnh Trà Vinh được giải thích bởi các biến độc lập trong mô hình nghiên cứu. Đó là các biến "Vốn sản xuất- X1", "Diện tích đất canh tác- X2", "Trình độ học vấn- X3", "Số nhân khẩu- X4", "Số hoạt động tạo thu nhập- X5", "Tình trạng việc làmD2" và "Sự hỗ trợ của Nhà nước/ Chính quyền địa phương cho hộ gia đình- D3". Hệ số Chi-square được sử dụng để kiểm định sự phù hợp của mô hình nghiên cứu. Nó kiểm định việc có nên bác bỏ giả thuyết null $\mathrm{H} 0$ : $\mathrm{B} 1=\mathrm{B} 2=\mathrm{B} 3=\mathrm{B} 4=\mathrm{B} 5=\mathrm{B} 6=\mathrm{B} 7=\mathrm{B} 8=\mathrm{B} 9=\mathrm{B} 10=\mathrm{B} 11=0$ hay không. Hệ số Chi-square của mô hình nghiên cứu trong nghiên cứu này đạt giá trị 25,012 , với bậc tự do df là 11 ; vì vậy giá trị mức ý nghĩa thực nghiệm tra bảng là 0,009 nhỏ hơn $1 \%$. Kết quả này bác bỏ giả thuyết null $\mathrm{H} 0$, thể hiện mức độ phù hợp tốt của mô hình nghiên cứu với tập dữ liệu phân tích tại mức ý nghĩa thông kê $1 \%$.

Thêm vào đó, Bảng 2 cũng xác nhận rằng, trong 11 biến độc lập trong mô hình, chỉ 7 biến có ảnh hưởng thống kê đến tình trạng nghèo đói của hộ gia đình tại tỉnh Trà Vinh. Các biến có ảnh hưởng thống kê lên biến phụ thuộc đó là "Vốn sản xuất- X1", "Diện tích đất canh tác- X2", "Trình độ học vấn- X3", "Số nhân khẩu- X4", "Số hoạt động tạo thu nhập- X5", "Tình trạng việc làm- D2" và "Sự hố trợ của Nhà nước/ Chính quyền địa phương cho hộ gia đình- D3". Các mối quan hệ này có ý nghĩa thống kê từ 1\%, $5 \%$ đến $10 \%$. "Trình độ học vấn của chủ hộ" và "Số hoạt động tạo thu nhập của hộ gia đình" là 2 yếu tố tác động đến tình trạng nghèo đói của hộ gia đình tại mức ý nghĩa thống kê $1 \%$; trong khi đó, "Diện tích đất canh tác của hộ gia đình" ảnh hưởng thống kê đến tình trạng nghèo đói của hộ gia đình tại mức ý nghĩa $10 \%$. Các biến ảnh hưởng còn lại "Vốn sản xuất của hộ gia đình", "Số nhân khẩu của hộ gia đình", "Tình trạng việc làm của chủ hộ" và "Sự hỗ trợ của Nhà nước/ Chính quyền địa phương cho hộ gia đình" thì ảnh hưởng đến tình trạng nghèo đói của hộ gia đình tại mức ý nghĩa thống kê $5 \%$. Biến "Tình trạng việc làm của chủ hộ" ảnh hưởng mạnh nhất lên tình trạng nghèo đói của hộ gia đình với hệ số là $(-1,993)$. Ảnh hưởng mạnh nhì là "Số nhân khẩu trong hộ gia đình". Trong 7 biến ảnh hưởng, biến "Diện tích đất canh tác của hộ gia đình" là yếu tố tác động ít nhất đến tình trạng nghèo đói của hộ gia đình với trọng số là $(-0,002)$; kế đến là yếu tố "Vốn sản xuất". Yếu tố "Trình độ học vấn của chủ hộ" là biến có mức ảnh hưởng $(-0,119)$ ít hơn trong 3 biến còn lại; 2 biến kia "Số hoạt động tạo thu nhập của hộ gia đình" và "Sự hỗ trợ của Nhà nước/ Chính quyền địa phương cho hộ gia đình" có mức ảnh hưởng là tương đương với hệ số ảnh hưởng bằng nhau là $(-0,296)$. Các biến độc lập còn lại trong 11 biến độc lập của mô hình nghiên cứu là "Độ tuổi lao động trong hộ gia đình", "Nghề nghiệp chính của hộ gia đình", "Giới tính của chủ hộ" và "Loại dân tộc của hộ gia đình" không có ảnh hưởng thống kê đến tình trạng nghèo đói của hộ gia đình tại tỉnh Trà Vinh. Kết quả từ phân tích hồi quy nhị phân Binary Logistic dẫn đến một số nhận định sau về tác động của các biến độc lập lên xác suất rơi vào diện nghèo đói của các hộ gia đình tại tỉnh Trà Vinh.

Biến "Vốn sản xuất của hộ gia đình cho sản xuất" ảnh hưởng đến xuất suất nghèo đói của hộ gia đình với ý nghĩa thống kê $5 \%$ và có dấu âm (-) với hệ số tương quan là $(-0,061)$; nghĩa là biến độc lập này có quan hệ nghịch biến với biến phụ thuộc. Hộ nghèo thường bị hạn chế trong việc tiếp cận nguồn tín dụng chính thức của Chính phủ/ Chính quyền địa phương. Hiện nay, có nhiều nguồn tín dụng giúp cho người nghèo thoát nghèo thông qua các chương trình, dự án quốc gia về xóa đói giảm nghèo; tuy nhiên, vẫn còn rất nhiều người nghèo không thể tiếp cận các nguồn tín dụng này. Kết quả này cho thấy rằng, nếu hộ gia đình tiếp cận được nguồn vốn và đầu tư càng nhiều cho hoạt động sản xuất tạo thu nhập thì xác suất nghèo đói của hộ càng giảm. Mối tương quan giữa biến "Diện tích đất canh tác của hộ gia đình" và "Tình trạng nghèo đói của hộ gia đình" có ý nghĩa thống kê tại mức $10 \%$ và mang dấu âm (-) với hệ số tương quan là $(-0,002)$; tức là mối quan hệ này thuộc loại nghịch biến. Những con số này hàm ý rằng, nếu hộ gia đình có đất canh tác càng nhiều, với các điều kiện tư liệu sản xuất khác không thay đổi, thì khả năng nghèo đói của họ sẽ giảm đi. Đất canh tác là tư liệu sản xuất quan trọng nhất trong nông nghiệp, nhất là ngành nuôi trồng để tạo thu nhập cho hộ gia đình. Việc thiếu đất canh tác sẽ khiến hộ gia đình phải đi thuê đất, hoặc phải chuyển sang các ngành nghề phi nông nghiệp khác, hoặc phải đi làm thuê tạo thu nhập nuôi sống gia đình và bản thân. Do đó, đất canh tác là tư liệu sản xuất cơ bản, rất cần thiết để tạo ra nguồn thu nhập cho hộ gia đình trong sản xuất nông nghiệp, nhất là ngành nuôi trồng.

Kết quả thực tế phân tích hồi quy nhị phân Binary Logistic cũng cho thấy, "Trình độ học vấn của chủ 
hộ" tác dụng ngược chiều lên tình trạng nghèo đói của hộ gia đình với hệ số ảnh hưởng là $(-0,119)$ tại mức ý nghĩa thống kê là $1 \%$. Điều này có nghĩa là, trình độ học vấn của chủ hộ gia đình càng cao, thì khả năng nghèo đói của hộ đó càng giảm; hay nói cách khác chủ hộ có học thức càng cao thì mức độ giàu có của hộ này càng cao. Trình độ học vấn là một khía cạnh rất quan trọng để đánh giá chất lượng của nguồn nhân lực. Nguồn nhân lực là yếu tố đầu vào của quá trình tạo ra thu nhập. Chất lượng của nguồn nhân lực là cao khi trình độ chuyên môn cao và kỹ năng lao động thành thạo. Trong đó, trình độ học vấn của người lao động là yếu tố rất đáng quan tâm, nó giúp cho người lao động nắm bắt được những kiến thức mới. Nó còn là một công cụ giúp người lao động tiếp cận được những tri thức mới, từ đó nâng cao khả năng tư duy sáng tạo của họ. Số nhân khẩu trong hộ gia đình có ý nghĩa thống kê tại mức $5 \%$, và mang dấu dương $(+)$; đây là mối quan hệ nhân quả đồng biến giữa "Số nhân khẩu trong hộ gia đình" và "Tình trạng nghèo đói của hộ gia đình" với hệ số tương quan là 1,869 . Thường thì số nhân khẩu trong hộ gia đình tăng lên đồng nghĩa với việc có nhiều người ăn hơn nhưng lại có ít lao động hơn. Điều này khiến các thành viên có lao động tạo nguồn thu phải chịu gánh nặng chi tiêu của hộ gia đình lớn hơn, vì họ phải cưu mang luôn cho số người lệ thuộc trong hộ gia đình; do vậy có tác động làm cho khả năng nghèo đói của hộ này sẽ cao hơn. Số nhân khẩu trong hộ gia đình càng cao thì thu nhập bình quân từ các nguồn tạo thu nhập của hộc gia đình sẽ giảm theo.

Bảng 2: Kết quả hồi quy nhị phân về tình trạng nghèo của hộ gia đình

\begin{tabular}{|c|c|c|c|}
\hline Biến số & Hệ số Beta (B) & Sai số chuẩn & $\operatorname{Exp}(B)$ \\
\hline Hằng số & $0,182^{*}$ & 0.0983 & 1.200 \\
\hline Vốn sản xuất (X1) & $-0,061 * *$ & 0.0275 & 0.941 \\
\hline Diện tích đất canh tác (X2) & $-0,002 *$ & 0.0012 & 0.998 \\
\hline Trình độ học vấn (X3) & $-0,119 * * *$ & 0.0339 & 0.888 \\
\hline Số nhân khẩu (X4) & $1,869 * *$ & 0.7428 & 6.482 \\
\hline Số hoạt động tạo thu nhập (X5) & $-0,296 * * *$ & 0.0333 & 0.744 \\
\hline Độ tuổi (X6) & $-0,030$ & 0.0315 & 0.970 \\
\hline Nghề nghiệp (D1) & 0.112 & 0.0939 & 1.119 \\
\hline Tình trạng việc làm (D2) & $-1,993 * *$ & 0.8266 & 0.136 \\
\hline Sự hỗ trợ (D3) & $-0,296 * *$ & 0.1481 & 0,744 \\
\hline Giới tính (D4) & $-0,032$ & 0.1711 & 0.969 \\
\hline Dân tộc (D5) & $-0,021$ & 0.2188 & 0.979 \\
\hline Chi-square/df & \multicolumn{3}{|c|}{$25,012 / 11$} \\
\hline Sig. & \multicolumn{3}{|c|}{0,009} \\
\hline Cox \& Snell-R ${ }^{2}$ & \multicolumn{3}{|c|}{0,354} \\
\hline
\end{tabular}

Biến phụ thuộc: Tình trạng nghèo của hộ gia đình

***, *. *: Mức ý nghĩa thống kê lần lượ là 1\%, 5\% và $10 \%$

Số hoạt động tạo thu nhập của hộ gia đình trong kết quả phân tích hồi quy nhị phân Binary Logistic ảnh hưởng lên tình trạng nghèo đói của hộ gia đình ở mức ý nghĩa thống kê là $1 \%$ với hệ số ảnh hưởng là $(-0,296)$. Số liệu âm cho thấy, khi số hoạt động tạo thu nhập của hộ gia đình tăng lên sẽ làm giảm khả năng nghèo đói của hộ gia đình xuống. Điều này nói lên rằng, các hộ gia đình có nhiều nguồn tạo thu nhập sẽ có khả năng năng cao thêm thu nhập của hộ gia đình, và vì vậy sẽ giảm được khả năng rơi vào nghèo đói. Sự đa dạng các hoạt động tạo thu nhập sẽ giúp hộ gia đình giảm rủi ro thất bại khi tham gia sản xuất hoặc kinh doanh để tạo nguồn thu cho gia đình; nếu ngành nghề này gặp rủi ro thất bại thua lỗ, thi có thể có ngành khác lại thành công, vì vậy thu nhập của hộ gia đình sẽ được quân bình và sẽ không quá thất bại. Tình trạng việc làm của chủ hộ gia đình có tác động nghịch biến lên tình trạng nghèo đói của hộ gia đình này. Mối quan hệ này đạt ý nghĩa thống kê tại mức 5\% với hệ số tương quan âm là $(-1,993)$. 
Kết quả này có ý nghĩa rằng, nếu chủ hộ gia đình có việc làm ổn định, thì khả năng hộ đó rơi vào diện hộ nghèo là thấp; trong khi đó, hộ gia đình có chủ hộ không có việc làm ổn định, thì thu nhập kiếm được của hộ gia đình này sẽ thấp hơn và vì vậy tăng xác suất rơi vào diện hộ nghèo đói. Tình trạng việc làm là yếu tố quan trọng để tạo thu nhập cho hộ gia đình. Như vậy, tình trạng việc làm của chủ hộ gia đình là yếu tố quan trọng trong việc giảm nghèo đói cho các hộ gia đình.

Sự hỗ trợ của Nhà Nước/ Chính quyền địa phương cho hộ gia đình có ảnh hưởng thống kê và mang dấu âm (-), tương quan nghịch biến với tình trạng nghèo đói của hộ gia đình. Theo số liệu từ phân tích hồi quy nhị phân Binary Logistic, mối quan hệ nhân quả giữa "Sự hỗ trợ của Nhà Nước/ Chính quyền địa phương cho hộ gia đình" và "Khả năng rơi vào diện nghèo đói của hộ gia đình" đạt ý nghĩa thống kê 5\% với hệ số tương quan là $(-0,296)$. Nếu các hộ gia đình nhận càng nhiều sự hỗ trợ từ Nhà Nước/ Chính quyền địa phương, thì nguồn thu nhập của họ sẽ càng tăng, điều này có nghĩa là xác suất rơi vào diện nghèo đói của các hộ này sẽ giảm đi. Chính sách hỗ trợ cho các hộ nghèo ở những vùng khó khăn được ưu tiên hàng đâu nhằm ổn định cuộc sống của dân cư, khuyến khích phát triển sản xuất. Có nhiều chính sách hỗ trợ của Nhà nước/ Chính quyền địa phương cho các hộ gia đình nghèo khó, ở những vùng đặc biệt khó khăn về đất đai, $\mathrm{y}$ tế, tài chính. Chính sách này còn hỗ trợ về đào tạo nguồn nhân lực, giải quyết vấn đề nước sạch và hô̂ trợ phòng chống thiên tai cho vùng sâu vùng xa, vùng còn nghèo đói. Các biến "Độ tuổi của lao động của hộ gia đình", "Nghề nghiệp chính của hộ gia đình", "Giới tính của chủ hộ" cũng như "Dân tộc của hộ gia đình" không có ảnh hương thống kê đến khả năng nghèo đói của hộ gia đình tại Trà Vinh. Kết quả này hàm ý rằng, độ tuổi trung bình của hộ gia đình cao hay thấp cũng không quan trọng gì đến thu nhập của hộ gia đình; hộ gia đình làm nghề gì cũng không có tác động đến thu nhập của họ, tức là nghề nào cũng có thể tạo ra thu nhập tốt cho họ gia đình nếu thích hợp với gia đình họ; chủ hộ gia đình là nam hay nữ thì khả năng tạo thu nhập là không khác biệt nhau và vì vậy không ảnh hưởng đến khả năng rơi vào diện nghèo đói của hộ gia đình; và cuối cùng các hộ dân tộc kinh cũng có khả năng rơi vào nghèo đói tương đương các hộ dân tộc khác.

\section{KẾT LUẬN}

Công tác xóa đói giảm nghèo là mục tiêu xuyên suốt trong quá trình phát triển kinh tế- xã hội của đất nước ta. Nó là yếu tố cơ bản để đảm bảo dân giàu, nước mạnh, xã hội công bằng và tăng trưởng kinh tế bền vững, đáp ứng mục tiêu do Đảng ta đề ra. Trong thời gian qua, công cuộc xóa đói giảm nghèo ở đất nước ta nói chung và ở tỉnh Trà Vinh nói riêng đã thu được những kết quả đáng khích lệ. Tuy nhiên, tỷ lệ hộ nghèo vẫn còn cao, con số cụ thể năm 2015 là $11 \%$, số liệu này cho thấy rằng, Trà Vinh là một trong những tỉnh nghèo nhất ở Đồng Bằng Sông Cửu Long. Do đó, ban lãnh đạo tỉnh Trà Vinh cần phải cố gắng hơn nữa để giảm tỷ lệ hộ nghèo ở tỉnh nhà xuống mặt bằng chung của các tỉnh Đồng Bằng Sông Cửu Long cũng như của cả nước. Để thực hiện được mục tiêu này, cần có những nghiên cứu liên quan đến tình trạng nghèo đói của cư dân tỉnh Trà Vinh.

Công trình nghiên cứu đề xuất 11 yếu tố có thể ảnh hưởng đến tình trạng nghèo đói củ dân dư ở tỉnh Trà Vinh. Tuy nhiên, kết quả nghiên cứu thực nghiệm từ dữ liệu về tình trạng nghèo đói của hộ gia đình tại tỉnh Trà Vinh cho thấy rằng, chỉ có 7 yếu tố tác động thống kê đến tình trạng nghèo đói của hộ gia đình tại tỉnh Trà Vinh, với mức tác động của từng yếu tố khác nhau. Yếu tố "Tình trạng việc làm của chủ hộ" ảnh hưởng mạnh nhất lên tình trạng nghèo đói của hộ gia đình. Ảnh hưởng mạnh nhì là "Số nhân khẩu trong hộ gia đình". Yếu tố "Diện tích đất canh tác của hộ gia đình" là yếu tố tác động ít nhất đến tình trạng nghèo đói của hộ gia đình; kế đến là yếu tố "Vốn sản xuất". Yếu tố "Trình độ học vấn của chủ hộ" là yếu tố có mức ảnh hưởng ít hơn trong 3 yếu tố còn lại; 2 yếu tố kia "Số hoạt động tạo thu nhập của hộ gia đình" và "Sự hỗ trợ của Nhà nước/ Chính quyền địa phương cho hộ gia đình" cùng có mức ảnh hưởng tương đương đến tình trạng nghèo đói của hộ gia đình. Bốn yếu tố độc lập còn lại trong 11 yếu tố độc lập của mô hình nghiên cứu là "Độ tuổi lao động trong hộ gia đình", "Nghề nghiệp chính của hộ gia đình", "Giới tính của chủ hộ" và "Loại dân tộc của hộ gia đình" không có ảnh hưởng thống kê đến tình trạng nghèo đói của hộ gia đình tại tỉnh Trà Vinh. Từ kết quả phân tích trên đây, nghiên cứu này đề xuất một số hàm ý chính sách nhằm nâng cao thu nhập của hộ gia đình với mục đích cuối cùng là giảm khả năng rơi vào diện nghèo đói cho các hộ dân cư tại tỉnh Trà Vinh. 
TẠI TỈNH TRÀ VINH

Về vốn sản xuất của hộ gia đình: Việc thiếu vốn sản xuất đã làm hạn chế khả năng tham gia các hoạt động tạo thêm thu nhập cho các hộ gia đình, vì thế cần một giải pháp về tài chính cho hộ gia đình, nhất là các hộ gia đình nghèo. Nhà nước/ Chính quyền địa phương cần có chính sách hợp lý nhằm đa dạng hóa các loại hình hỗ trợ tín dụng cho các hộ gia đình ở vùng khó khăn, đặc biệt chú trọng các dự án hỗ trợ có tính chất nước ngoài đối với đối tượng này; mở rộng hoạt động tín dụng cho hộ nghèo về số lượng tiền vay, đơn giản thủ tục vay và tăng thời hạn vay, phải gắn chặt với các đoàn thể, chính quyền địa phương và hệ thống khuyến nông, để đáp ứng đầy đủ nhu cầu vốn của các hộ nghèo. Về phía hộ gia đình, người vay vốn sản xuất cần phải có kế hoạch rõ ràng về thanh toán tiền lãi hoặc tiền gốc cho bên ngân hàng cho vay đúng thời hạn ghi trong hợp đồng, không nên để bị liệt vào danh sách khách hàng nợ xấu, gây khó khăn cho ngân hàng và cũng ảnh hưởng đến các đối tượng cần vay khác.

Về diện tích đất canh tác: Việc thiếu đất canh tác sẽ hạn chế các hộ gia đình chuyên làm nông nghiệp tạo ra thu nhập cho gia đình, vì họ thiếu tư liệu sản xuất. Nhà nước/ Chính quyền địa phương cần có chính sách thích hợp nhằm tăng cường giáo dục, tuyên truyền, động viện các hộ nghèo hạn chế tình trạng sang nhượng hoặc cầm cố đất đai. Nên có chủ trương khuyến khích các hộ nghèo có ít đất sản xuất cần liên kết lại với nhau góp vốn bằng quỹ đất để cùng sản xuất, và cùng thoát nghèo bền vững. Ngoài ra, cần quan tâm các biện pháp thâm canh, tăng năng suất nhằm làm tăng sản lượng trên một đơn vị diện tích và nâng cao hiệu quả sử dụng đất nông nghiệp. Nhà nước/ Chính quyền địa phương cũng cần hỗ trợ cho các hộ nghèo thiếu đất hoặc không có đất sản xuất bằng vốn vay ưu đãi, cấp đất sản xuất phù hợp. Đối với cư dân địa phương, nông dân nên nhận thức tầm quan trọng của đất canh tác, vì đó là tư liệu sản xuất của người nông dân, và cần thiết giáo dục con em mình không được bán đi đất canh tác để tiêu xài, mà nên tích lũy thêm đất đai để tăng năng lực sản xuất nông nghiệp tạo thêm công ăn việc làm và tăng thu nhập cho hộ gia đình.

Về trình độ học vấn của chủ hộ: Trình độ học vấn của chủ hộ gia đình ảnh hưởng khá mạnh đến tình trạng nghèo đói của hộ gia đình. Chủ hộ là người trụ cột gia đình, vì thế trình độ học vấn của chủ hộ càng cao, thì họ càng biết cách tạo ra nguồn thu nhập cho gia đình họ, và khả năng nghèo của họ sẽ thấp. Do đó, Nhà nước/ Chính quyền địa phương cần có chính sách thích hợp nhằm nâng cao trình độ học vấn của chủ hộ nói riêng và của dân cư địa phương nói chung để góp phần tăng thu nhập và xóa đói giảm nghèo cho hộ nghèo ở địa phương. Để thực hiện được mục tiêu này, Nhà nước/ Chính quyền địa phương cần có chính sách sau đây. Đối với những chủ hộ có trình độ thấp, Nhà nước/ Chính quyền địa phương cần vận động người dân tham gia phổ cập giáo dục nâng cao trình độ tri thức, thành lập các câu lạc bộ đọc sách, xây dựng thư viện, mở lớp giáo dục thường xuyên bồi dưỡng trình độ văn hóa cho người thất học, đào tạo nâng cao tay nghề cho người dân, đặc biệt chú trọng đối tượng hộ gia đình nghèo; và cũng cần có chính sách hợp lý kết hợp đào tạo nghề với phổ cập văn hóa cho những đối tượng thất học không có kỹ năng nghề nghiệp. Đối với các thế hệ tương lai, Nhà nước/ Chính quyền địa phương cần có chính sách mở rộng mạng lưới các trường trung học cơ sở, trung học phổ thông người nội trú ở cấp huyện và liên xã; đẩy mạnh sự nghiệp giáo dục mầm non trên địa bàn mỗi xã, đào tạo đội ngũ cán bộ giảng dạy cả về số lượng lẫn chất lượng; thành lập quỹ khuyến học riêng nhằm hỗ trợ những con em hộ gia đình có hoàn cảnh khó khăn được đến trường; huy động tối đa trẻ em trong độ tuổi được đi học ở tất cả các bậc học, hạn chế tình trạng bỏ học của các em học sinh trong độ tuổi trung học cơ sở và trung học phổ thông. Về phía hộ gia đình, người dân nên tự ý thức nâng cao trình độ học vốn và tay nghề bằng cách tìm kiếm những lớp học liên quan để tham gia, từ đó sẽ tiếp cận được với khoa học kỹ thuật tiên tiến hơn nhằm nâng cao năng suất sản xuất và tạo thêm thu nhập cho mình. Chủ hộ cũng cần khuyến khích con em tham gia trường lớp đầy đủ, và giải thích cho chúng biết được tầm quan trọng của trình độ học vấn và chuyên môn trong công việc làm của chúng trong tương lai.

Về số nhân khẩu trong hộ gia đình: Số nhân khẩu hay quy mô hộ gia đình càng lớn thì khả năng nghèo đói của hộ gia đình càng cao. Quy mô gia đình càng lớn thì khoảng chi tiêu của gia đình càng cao, trong thu nhập chung của gia đình thì không tăng nhiều. Nhà nước/ Chính quyền địa phương cần có một số chủ trương để giảm tối ưu quy mô gia đình của hộ gia đình, nhất là gia đình nghèo. Nhà nước/ Chính quyền địa phương nên thông qua công tác tuyên truyền, vận động nhằm nâng cao vai trò và nhận thức của phụ nữ, giúp họ có quyền bình đẳng trong gia đình để hạn chế phải sinh con thứ ba trở lên hoặc kéo dài 
thời gian giữa 02 lần sinh con. Thêm vào đó, Nhà nước/ Chính quyền địa phương cần tích cực vận động và khuyến khích phụ nữ tham gia các hoạt động hội đoàn thể, nhất là Hội Liên hiệp Phụ nữ, để họ trao đổi, học hỏi nhau kiến thức về sức khỏe sinh sản, kế hoạch hóa gia đình, kiến thức nuôi dạy con, học hỏi cách làm kinh tế gia đình, từ đó họ sẽ ý thức được việc sinh con nhiều là sẽ cản trở viêc phát triển kinh tế hộ gia đình và gây khó khăn cho những người chủ gia đình. Nếu đã ý thức được, thì họ sẽ giảm việc sinh con thứ ba, thứ tư; điều này sẽ làm giảm quy mô hộ gia đình và cuối cùng sẽ giảm khả năng rơi vào diện nghèo đói của gia đình họ. Người dân cần tuyên truyền nhau về chính sách hộ gia đình không nên sinh nhiều con, nên tuân theo quy định của Nhà nước: mỗi gia đình chỉ được sinh 2 con dù trai hay gái, điều này sẽ giảm áp lực nuôi dạy con cái lên cha mẹ, và vì vậy cha mẹ có nhiều thời gian hơn để tham gia sản xuất, tăng thu nhập và làm giàu.

Về số hoạt động tạo thu nhập: Sự đa dạng hóa các hoạt động tạo nguồn thu nhập sẽ làm tăng cơ hội tạo thu nhập cho hộ gia đình. Do vậy, để giúp tăng nguồn thu cho các hộ gia đình, Nhà nước/ Chính quyền địa phương cần phải đa dạng hóa các hoạt động tạo thu nhập cho người dân địa phương. Muốn thực hiện được điều này, cần phải có sự chung tay của các hộ gia đình và sự hỗ trợ của Nhà nước/ Chính quyền địa phương. Để đa dạng hóa các hoạt động tạo nguồn thu nhập cho hộ gia đình, Nhà nước/ Chính quyền địa phương cần có một số chính sách thích hợp sau đây. Nhà nước/ Chính quyền địa phương cần khuyến khích các thành viên hộ gia đình, nhất là chủ hộ tích cực tham gia học nghề, tích cực tham gia và sáng tạo các hoạt động tạo nguồn thu nhập, đặc biệt là các hoạt động phi nông nghiệp nhằm phát huy các nguồn lực sẵn có của hộ; cần phát triển các lớp dạy nghề cho người dân địa phương, đồng thời có chính sách hỗ trợ cho các cơ sở sản xuất, các tổ chức kinh tế hợp tác, các doanh nghiệp, các chủ trang trại để họ làm ăn có hiệu quả tại địa phương, tạo điều kiện cho các đơn vị này tạo thêm ngành nghề, việc làm cho người dân. Có chính sách ưu đãi thỏa đáng đối với các đơn vị có sử dụng nhiều lao động thuộc hộ nghèo tại địa phương. Người dân cần nâng cao nhận thức về tầm quan trọng của việc học hỏi, nâng cao trình độ, tay nghề; cố gắng tham gia các lớp học nghề, các buổi tập huấn do các cơ quan tổ chức tại địa phương để có thêm kiến thức về nghề nghiệp mới, từ đó có thể tham gia thêm và công việc mới nhằm tạo thêm thu nhập cho hộ gia đình.

Về tình trạng việc làm: Tạo công ăn việc làm cho hộ gia đình sẽ giảm tình trạng thất nghiệp, và vì vậy giảm khả năng rơi vào nghèo đói cho các hộ gia đình. Để thực hiện tốt công tác tạo công ăn việc làm cho người dân, Nhà nước/ Chính quyền địa phương cần quản lý sử dụng hiệu quả nguồn vốn vay hỗ trợ việc làm, tổ chức xét duyệt đúng đối tượng giải ngân cho các dự án, đảm bảo sử dụng vốn đúng mục đích và phát huy hiệu quả vốn vay, thu hút nhiều lao động tham gia nhằm giải quyết việc làm. Bên cạnh đó, Nhà nước/ Chính quyền địa phương cần có chính sách phù hợp nhằm đẩy mạnh công tác đào tạo nghề, và giải quyết việc làm cho người dân địa phương; tập trung cho công tác đào tạo nghề gắn với thị trường lao động; đầu tư trang thiết bị, cơ sở vật chất, mở rộng các hình thức đào tạo nghề, liên kết, liên thông đào tạo, khuyến khích các doanh nghiệp xây dựng cơ sở dạy nghề; tập trung dạy nghề nông thôn cho người lao động, nhất là người nghèo. Nhà nước/ Chính quyền địa phương cũng cần khuyến khích và tạo điều kiện để các doanh nghiệp sản xuất công nghiệp sử dụng nhiều lao động, mở rộng đầu tư phát triển sản xuất và ưu tiên tuyển dụng lao động là con em của các hộ nghèo. Người dân địa phương nên nâng cao tinh thần bổ sung kiến thức khoa học kỹ thuật, kỹ năng quản lý, kiến thức thị trường để lựa chọn thêm những nghề phù hợp, từ đó tạo cho mình những công ăn việc làm ổn định, nhằm duy trì được nguồn thu nhập ổn định cho hộ gia đình và thoát được nghèo đói.

Về sự hỗ trợ của Nhà nước/ Chính quyền địa phương cho hộ gia đình: Sự hỗ trợ của Nhà nước/ Chính quyền địa phương là rất cần thiết cho hộ gia đình nghèo để giúp hộ phát triển kinh tế. Việc nhận được hỗ trợ từ Nhà nước/ Chính quyền địa phương sẽ làm tăng thu nhập của hộ gia đình, đặc biệt là các hộ gia đình nghèo. Nhà nước/ Chính quyền địa phương cần thực hiện có hiệu quả các chính sách hỗ trợ người nghèo như miễn giảm học phí, bảo hiểm y tế, khám chữa bệnh miễn phí, hỗ trợ xây dựng nhà ở, cứu trợ, cứu đói nhằm giúp họ từng bước ổn định cuộc sống và vươn lên thoát nghèo. Thêm vào đó, cán bộ thực hiện công tác xóa đói giảm nghèo ở địa phương cần nắm chắc tình trạng nghèo đói của các hộ gia đình tại địa phương và thường xuyên theo dõi hỗ trợ, hướng dẫn họ phương cách làm ăn, giúp họ thoát nghèo bền vững. Nhà nước/ Chính quyền địa phương cũng cần có những chính sách thích hợp nhằm 
khuyến khích cộng đồng dân cư, thôn xóm đề cao trách nhiệm hỗ trợ các hộ nghèo trên tinh thần "tương thân tương ái" với những hình thức hỗ trợ phong phú như cho mượn tư liệu sản xuất, hỗ trợ vốn, giúp nhân công, liên kết đất sản xuất; điều này sẽ giúp họ hòa nhập với cộng đồng, phát triển sản xuất, tạo thu nhập và thoát nghèo bền vững. Nhà nước nên chuyển những hình thức trợ cấp thường xuyên sang các hình thức đào tạo nghề và khuyến khích người nghèo học nghề để tự họ thoát nghèo. Đối với chính sách hộ trợ hộ nghèo của Nhà nước/ Chính quyền địa phương, người dân cần tự nguyện tham gia, cam kết thực hiện đầy đủ và đúng các quy định, quy trình sản xuất của Nhà nước, nên đáp ứng điều kiện về sản xuất như đất đai, lao động, trang thiết bị phù hợp với từng dự án hỗ trợ, nhằm tăng tính hiệu quả của chính sách hỗ trợ.

Với những hàm ý chính sách nhằm góp phần nâng cao thu nhập cho các hộ nghèo được đề xuất trên đây, tác giả hy vọng Nhà nước/ Chính quyền địa phương sẽ xem xét và thực thi những hàm ý này nhằm nâng cao thu nhập, xóa đói giảm nghèo, với mục đích cuối cùng là cải thiện đời sống cho người dân tại tỉnh Trà Vinh. Tác giả cũng kỳ vọng rằng, kết quả từ nghiên cứu này sẽ góp một phần nhỏ giúp lãnh đạo tỉnh Trà Vinh trong mục tiêu xóa đói giảm nghèo của tỉnh nhà, nhằm từng bước nâng cao đời sống vật chất và tinh thần của cư dân địa phương, đưa kinh tế của tỉnh Trà Vinh phát triển nhanh và bền vững.

\section{TÀI LIẸU THAM KHẢO}

[1] Nguyễn Thị Ánh và Nguyễn Thị Nghĩa (2014) Thực trạng, giải pháp xóa đói giảm nghèo đối với đồng bào dân tộc khmer ở khu vực đồng bằng Sông Cửu Long, Tạp chí Khoa học Trường Đại học Cần Thơ, 30(2014), $84-91$

[2] Võ Ngọc Ánh (2008) Tìm hiểu một số yếu tố ảnh hưởng đến nghèo đói ở xã Núi Tô, huyện Tri Tôn, tỉnh An Giang, Luận văn, Khoa Nông Nghiệp - Tài Nguyên Thiên Nhiên, Đại Học An Giang

[3] Cục Thống kê tỉnh Trà Vinh (2015) Niên giám thống kê tỉnh Trà Vinh 2014, NXB Thanh Niên

[4] Cục Thống kê tỉnh Phú Thọ (2014) Hướng dẫn tạm thời về phương pháp thống kê, đánh giá mức độ đạt các tiêu chí thu nhập, hộ nghèo và lao động có việc làm thường xuyên trong: Bộ tiêu chí nông thôn mới áp dụng đối với xã tỉnh Phú Thọ, Công văn số 51/HD-CTK

[5] Nguyễn Minh Hà, Lê Công Thành và Nguyễn Hữu Tịnh (2013) Các yếu tố tác động đến tình trạng tái nghèo của hộ gia đình (Trường hợp huyện Châu Thành, tỉnh Đồng Tháp), Tạp Chí Khoa học Xã hội, 5(177), 13-21

[6] Hoàng Triều Hoa (2014) Giảm nghèo bền vững tại Việt Nam: Hỗ trợ từ chính sách giáo ục, y tế, Tạp chí Kinh tế và Dự báo, số 12 , tháng 6/2014

[7] Ngân hàng Thế giới (2012) Báo cáo đánh giá nghèo Việt Nam 2012: "Khởi đầu tốt, nhưng chưa phải đã hoàn thành: thành tựu ấn tượng của Việt Nam về giảm nghèo và những thách thức mới”, Ngân hàng Thế giới tại Việt Nam- Hà Nội, Việt Nam

[8] Nguyễn Thị Hoàng Phượng (2009) Thực trạng nghèo ở xã Phú Xuân huyện Phú Tân, Kỷ yếu hội thảo khoa học, Trường Đại Học An Giang, Tỉnh An Giang

[9] Quyết định số 1049/QĐ-TTg, ngày 26 tháng 4 năm 2014 của Thủ tướng Chính phủ về việc ban hành danh mục các đơn vị hành chính thuộc vùng khó khăn

[10] Quyết định số 09/QĐ-TTg, ngày 30/01/2011 của Thủ tướng Chính phủ về việc ban hành chuẩn hộ nghèo, cận nghèo áp dụng cho giai đoạn 2011-2015

[11] Ngô Thị Lệ Thủy (2006) Giáo trình bài giảng phân hóa giàu nghèo ở Việt Nam, NXB Đại Học Cần Thơ 
[12] Lê Đại Trí, Trần Triệu Ngõa Huyến, Nguyễn Nhật Quang, Tô Thùy Hương, Nguyễn Thị Thanh Binh, Lê Công Minh, Nguyễn Thị Nhẫn và Nguyễn Lê Hạnh (2003) Đánh giá nghèo có sự tham gia của cộng đồng tại đồng bằng sông Cửu Long, NXB Lao động - Xã hội

[13] Phạm Anh Tuấn, Hoàng Xuân Quyến, Trần Văn Long, Vũ Thị Phê, Vũ Xuân Đào, Ann Marie Aase, Nguyễn Đình Quân, Lương Văn Chương và Lê Đông Phương (2003) Đánh giá nghèo đói có sự tham gia của cộng đồng tại Ninh Thuận, Ngân hàng thế giới tại Việt Nam

[14] Hair J. F., Black W.C., Babin B. J., Anderson R.E. and Tatham R.L. (2010) Multivariate Data Analysis, Ed., New Jersey: Pearson Prentice Hall, USA

[15] World Bank (2000) World Development Report 2000/2001: Attacking Poverty; Washington, DC- World Bank, USA

Ngày nhận bài: 04/01/2017

Ngày chấp nhận đăng: 08/07/2017 